\title{
Comparison of the effects of two different marine-derived omega-3 fatty acid sources, krill oil, and fish oil, on the healing of primary colonic anastomoses after colectomy applied Wistar albino rat model
}

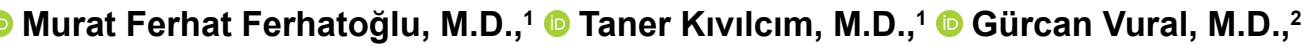

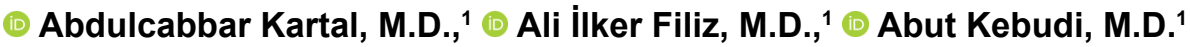

${ }^{1}$ Department of General Surgery, İstanbul Okan University Faculty of Medicine, İstanbul-Turkey
${ }^{2}$ Department of Pathology, İstanbul Okan University Faculty of Medicine, İstanbul-Turkey

ABSTRACT

BACKGROUND: Oils from marine organisms have a different fatty acid composition. Fish oil (FO) has a high content of eicosapentaenoic and docosahexaenoic acids esterified to triacylglycerols; while in krill oil (KO), fatty acids are primarily esterified to phospholipids. This study aimed to compare the efficacy of two different, marine-derived omega- 3 fatty acid sources in the wound healing of colon anastomoses rat model.

METHODS: For the study, we used 42 male Wistar albino rats. The rats were divided into six groups with seven rats in each groupCO3: left colonic anastomosis (control group), sacrificed on the third day; KO3: left colonic anastomosis + oral $\mathrm{KO}$, sacrificed on the third day; FO3: left colonic anastomosis + oral FO, sacrificed on the third day; CO7: left colonic anastomosis (control group), sacrificed on the seventh day; KO7: left colonic anastomosis + oral KO, sacrificed on the seventh day; FO7: left colonic anastomosis + oral FO, sacrificed on the seventh day. Peritoneal adhesions, anastomotic bursting pressures, hydroxyproline levels, and histological examination of the anastomotic tissue were evaluated.

RESULTS: On day 7, bursting pressure and hydroxyproline measurements of the $\mathrm{KO}$ group was significantly higher than the FO group ( $p=0.012 ; p=0.002$, respectively). Also, on day 7 , a statistically significant difference was observed between the groups according to inflammatory cell infiltration, fibroblast activity, neoangiogenesis, and collagen deposition in favor of the KO group $(p=0.023 ; p=0.028$; $\mathrm{p}=0.016 ; \mathrm{p}=0.012$, respectively).

CONCLUSION: Both KO and FO supplementation in patients before colorectal surgery may reduce some risk of anastomotic leakage; and $\mathrm{KO}$ might be a better alternative and excellent omega-3 source.

Keywords: Anastomotic healing; fish oil; krill oil; omega-3 fatty acids; primary colonic anastomosis.

\section{INTRODUCTION}

Fish oil (FO) is a rich source of long-chain n-3 polyunsaturated fatty acids, eicosapentaenoic acid, and docosahexaenoic acid. ${ }^{[1]}$ The overall fatty acid composition of krill oil $(\mathrm{KO})$ resembles that of $\mathrm{FO}$, same docosahexaenoic acid content but higher eicosapentaenoic acid. FO comprises the majority of these fatty acids as triglycerides, whereas $30 \%-65 \%$ of the fatty acids are stored as phospholipids in KO. ${ }^{[2]}$ Whether being esterified in triglycerides or phospholipids effects on the absorption efficiency of fatty acids into the blood and on the impact on serum lipid levels are controversial issues.

Cite this article as: Ferhatoğlu MF, Kıvılcım T, Vural G, Kartal A, Filiz Aİ, Kebudi A. Comparison of the effects of two different marine-derived omega-3 fatty acid sources, krill oil, and fish oil, on the healing of primary colonic anastomoses after colectomy applied Wistar albino rat model. Ulus Travma Acil Cerrahi Derg 2019;25:324-330.

Address for correspondence: Murat Ferhat Ferhatoğlu, M.D.

Istanbul Okan Üniversitesi Tıp Fakültesi, Genel Cerrahi Anabilim Dalı, 34734 Tuzla, İstanbul, Turkey

Tel: +90 216-677 1630 E-mail: ferhatferhatoglu@yahoo.co.uk

Ulus Travma Acil Cerrahi Derg 2019;25(4):324-330 DOI: 10.14744/tjtes.2019.0305I Submitted: 13.03.2019 Accepted: 24.06.2019 Online: 08.07.2019

Copyright 2019 Turkish Association of Trauma and Emergency Surgery 
The fourth most common cause of cancer deaths worldwide is colorectal cancer, ${ }^{[3]}$ and anastomosis leakage is one of the most severe complications of colorectal surgery. Despite the recent advances in surgical techniques and technologic devices, the anastomosis leakage occurs in up to $37 \%$ of patients with colorectal cancer. ${ }^{[4]}$ Most anastomoses are performed as a part of the treatment of colorectal cancer. After resection of the cancer, an anastomosis is made if it is found feasible and safe. Besides colorectal anastomosis, gastrointestinal anastomoses are performed in many other fields of gastrointestinal surgery as well. [5] Gastric and esophageal anastomoses are performed in the treatment of gastroesophageal cancer and obesity, pancreatico-jeonunal anastomoses in the treatment of pancreatic cancer, and biliary anastomoses in the treatment of benign as well as malignant diseases in the hepatobiliary system. The number of anastomoses in these fields is widely unknown. ${ }^{[6,7]}$ Anastomotic leakage is also a feared complication in these fields of surgery, and as in colorectal surgery, the consequences for the patients are severe.

Previous studies have shown that patients should receive a diet rich in long-chain polyunsaturated fatty acids to enhance the safety of anastomosis. ${ }^{[8,9]}$ The effect of long-chain n-3 polyunsaturated fatty acids esterified to phospholipids dietary support on the mechanical and inflammatory events surrounding anastomosis healing has never been determined.

This study aimed to investigate the effect of immediate longchain n-3 polyunsaturated fatty acids supports on colonic anastomotic healing in Wistar albino rat model.

\section{MATERIALS AND METHODS}

Animals: The researchers used 42 male Wistar albino rats with a mean weight of 284-367 g obtained from the Biological Experiments with Living Animals Laboratory of Uskudar University, Istanbul, Turkey. The rats were maintained on a regular laboratory rat diet (crude protein: $23 \%$, crude fat: $3.0 \%$, crude fiber: $7.0 \%$, acid insoluble ash: $8 \%$, calcium: $1 \%-$ $2.5 \%$, phosphorus: $0.9 \%$, sodium: $0.5 \%-1 \%$, moisture: $12 \%$. Ingredients: corn, soybean pulp, sunflower seed meal, shorts, Bonquality flour, alfalfa pellets, molasses, meat and bone meal, poultry meal, sepiolite, inorganic DCP, marble dust, vitamins, minerals) and tap water with a 12 -h day/night light cycle at a room temperature of $24^{\circ} \mathrm{C}-26^{\circ} \mathrm{C}$. We formed six groups containing seven rats in each group. The rats were housed as two per cage and allowed to mobilize freely.

Randomization: Rats were randomized into groups using computer-generated random numbers. None of the animals died during the study. For the study, six groups were formed as follows: $\mathrm{CO} 3(n=7)$ left colonic anastomosis (control group), sacrificed on the third day (KO or FO was not administrated); $\mathrm{KO} 3(\mathrm{n}=7$ ) left colonic anastomosis $+\mathrm{KO}$, sacrificed on the third day; FO3 $(n=7)$, left colonic anastomosis + FO, sacrificed on the third day; $\mathrm{CO} 7(n=7)$ left colonic anastomo- sis (control group) sacrificed on the seventh day (KO or FO was not administrated); $\mathrm{KO} 7(\mathrm{n}=7)$ left colonic anastomosis $+\mathrm{KO}$, sacrificed on the seventh day; FO7 $(n=7)$, left colonic anastomosis + FO, sacrificed on the seventh day.

Omega-3 sources: One red krill oil capsule (iHealht, Dikilitas/lstanbul): KO $500 \mathrm{mg}+$ eicosapentaenoic acid $66 \mathrm{mg}+$ docosahexaenoic acid $35 \mathrm{mg}+$ coline $25 \mathrm{mg}+$ astaxanthin 40 mg, 2- EFA 1200 capsule (Sifar İlac, Fenerbahce/lstanbul): eicosapentaenoic acid $396 \mathrm{mg}+$ docosahexaenoic acid 264 $\mathrm{mg}+$ other fatty acids $60 \mathrm{mg}$.

\section{Application of Omega-3 Sources}

KO3 and KO7: Thirty days before surgery, $\mathrm{KO} 3$ and $\mathrm{KO} 7$ received $\mathrm{KO}$ emulsion as an isocaloric and isovolumetric emulsion at a dose of $100 \mathrm{mg} / \mathrm{kg} /$ day eicosapentaenoic acid ( $1.8 \mathrm{ml} / \mathrm{kg} /$ day red $\mathrm{krill}$ oil capsule) through a rigid orogastric tube. On the $30^{\text {th }}$ day, the study begins; the $\mathrm{KO}$ feeding of the rats was stopped.

FO3 and FO7: Thirty days before surgery, FO3 and FO7 received $\mathrm{FO}$ emulsion as an isocaloric and isovolumetric emulsion at a dose of $100 \mathrm{mg} / \mathrm{kg} /$ day eicosapentaenoic acid $(0.25$ $\mathrm{ml} / \mathrm{kg} /$ day EFA 1200 capsule) through a rigid orogastric tube. On the $30^{\text {th }}$ day, the study begins; the FO feeding of the rats was stopped.

Surgical procedure: All rats were fasted for $8 \mathrm{~h}$ before surgery that was performed under sterile conditions by a surgeon who is uninformed about experimental groups. A veterinary who is an expert on biological experiments administrated general anesthesia with $50 \mathrm{mg} / \mathrm{kg}$ ketamine hydrochloride (Ketamine, Pfizer, New York, USA) intraperitoneally and $5 \mathrm{mg} / \mathrm{kg}$ xylazine hydrochloride (XYLAZINBIO $2 \%$, Bioveta, Cankaya, Ankara, Turkey) intramuscularly. Next, the anterior abdominal wall was shaved with an electric razor and wiped with povidone-iodine to obtain antiseptic conditions. After sterile drape covering, uninformed surgeon exposed the peritoneal cavity with a $4-\mathrm{cm}$ midline abdominal incision. After exploration of the abdominal cavity, the surgeon excluded the animals with gastrointestinal anomalies and intraabdominal tumors from the study. Following this elimination process, the surgeon performed a colo-colonic anastomosis. Left colon was mobilized, and a full-layer cut was created in a $90^{\circ}$ angle to the longitudinal axis of the colon. Next, the surgeon performed an end-to-end colo-colic anastomosis using a using 6/0 non-absorbable, monofilament polypropylene inverting, six, sutures (Ethicon, Somerville, New Jersey, USA). After anastomosis, the surgeon closed the abdominal wall with $3 / 0$ silk sutures (Dogsan, Besiktas, Istanbul, Turkey) and injected $10 \mathrm{ml} / \mathrm{kg}$ sterile saline subcutaneously for postoperative hydration at the end of the procedure. Animals were fasted for postoperative $24 \mathrm{~h}$, after which they were initiated on a standard diet and drinking water (not including $\mathrm{KO}$ or FO). 
Sacrification of rats: A veterinary who is an expert on biological experiments on animals sacrificed the rats using a guillotine.

Evaluation of adhesions: Post-mortem examination was conducted to grade adhesions on a scale from 0 to 3 according to the method introduced by van der Ham et al. ${ }^{[10]}$

Measurement of colonic anastomosis bursting pressure: The uninformed surgeon made bursting pressure measurements within $3 \mathrm{~min}$ of sacrifice. First, the anastomosis integrity was determined by exposing the anastomosis line and removal of the adhesions in the surrounding tissues. Next, two cuts, one $2 \mathrm{~cm}$ proximal and the other $2 \mathrm{~cm}$ distal to the anastomosis site, were made to obtain a $4-\mathrm{cm}$ long colonic segment. Fecal content of the colon was removed with physiologic saline solution. The distal end of the removed colon segment was ligated with small titanium clip (Ethicon, Somerville, New Jersey, USA) after an infusion set connected to a sphygmomanometer was inserted into the proximal end of the colon segment. The surgeon put the excised part of the colon in a beaker filled with a physiological saline solution and inflated with air. The intraluminal pressure was increased in $10-\mathrm{mmHg}$ increments and maintained for $10 \mathrm{~s}$. The appearance of air bubbles was used to record the bursting pressure in $\mathrm{mmHg}$. Notably, bursting occurred at the anastomosis line in all samples. The anastomosis leakage or dehiscence was determined if the bursting pressure of the resected colon segment was measured as $0 \mathrm{mmHg}$ or if the significant findings of leakage/dehiscence (abscess formation in the peritoneal cavity) were observed; these animals were excluded from the study. Next, the anastomosis segment was cut longitudinally and divided into two half rings; one half was placed in 10\% formalin solution for histopathological evaluation, and the other half was stored at $-80^{\circ} \mathrm{C}$ for hydroxyproline measurement.

Histopathological evaluation: The same pathologist who was blinded to the treatment groups sectioned the 10\% formalin-fixed colonic segments, stained them with hematoxylin and eosin, and analyzed them with light microscopy at 200x magnification by. Infiltration of inflammatory cells (leukocyte count), the activity of fibroblast cells, neoangiogenesis, and collagen content were measured using the modified Ehrlich and Hunt scale by Phillips et al. ${ }^{[1]}$ (0: no evidence, I: occasional evidence, 2: light scattering, 3: abundant evidence, 4: confluent cells or fibers).

Tissue hydroxyproline assay: The tissue concentrations of hydroxyproline, which represent perianastomotic collagen levels, were measured using the Rat hydroxyproline enzymelinked immunosorbent assay (ELISA) Kit (Bioassay Technology Laboratory, Shanghai, China, USA Cat. No E05IIRa). The values were expressed as nanogram amount of hydroxyproline per milliliter of tissue $(\mathrm{ng} / \mathrm{ml})$.

The detection principle of Rat hydroxyproline ELISA kit: This experiment uses a double-sandwich ELISA tech- nique and the ELISA kit provided is typical. The pre-coated antibody is rat hydroxyproline monoclonal antibody, and the detecting antibody is a polyclonal antibody with biotin-labeled. Samples and biotin labeling antibody are added into ELISA plate wells and washed out with $1.5 \mathrm{ml}$ of phosphate buffered saline. Then avidin-peroxidase conjugates are added to ELISA wells in order; tetramethylbenzidine substrate is used for coloring after reactant is thoroughly washed out by phosphate buffered saline. Tetramethylbenzidine turns into blue in peroxidase catalytic and finally turns into yellow under the action of the acid. The color depth and the testing factors in samples are positively correlated.

Power analysis: Power analysis was conducted using the G*Power (v3.1.9.2) program, to define the number of samples. The power of the study was confirmed as I- (= probability of type II error) and was set at $80 \%$. Based on the adhesion scores of previous studies, ${ }^{[12]}$ estimated from abscess formation, significance at a minimum of I unit with 0.7 units of standard deviation (SD). The resultant calculated effect size was $d=1.319$. To obtain $20 \%$ type II error (power is $80 \%$ ) at 0.05 level, it was decided to involve at least seven rats in each group.

\section{Statistical Analysis}

For statistical analysis, the Number Cruncher Statistical System (NCSS) 2007 (Kaysville, Utah, USA) program was used. Descriptive statistical methods (mean, SD, median, frequency, ratio, minimum, maximum) were used when evaluating the study data. The Mann-Whitney $U$ test was used to compare two groups of data that did not show normal distribution. Kruskal-Wallis test and Bonferroni-Dunn test were used in double comparisons. The Fisher-Freeman-Halton Exact test and Fisher's Exact test were used to compare the qualitative data. The Wilcoxon signed ranks test was used for intragroup comparisons of non-normally distributed parameters. Significance was evaluated at least $p<0.05$.

Ethical approval: This research followed the Guide for the Care and Use of Laboratory Animals published by the US National Research Council (Eight Edition 2010). Animal care was provided according to the standards proposed by the European Community (86/609/EEC). And the Istanbul, Uskudar University Board of Biological Experiments with Living Animals approved the experimental protocol (August 16, 2017-13).

\section{RESULTS}

The weight of the rats while the beginning of the experiment ranged between 280 and $367 \mathrm{~g}(304.7 \mathrm{I} \pm 24.42)$.

Macroscopic evaluation: No statistical difference was noticed according to groups on macroscopic evaluation parameters as anastomosis dehiscence/leakage, abscess formation in the peritoneal cavity. Moreover, adhesion score of $\mathrm{KO} 7$ was significantly lower than FO7 ( $\mathrm{p}=0.0 \mathrm{I})$ (Table I). 
Table I. Evaluation of anastomosis dehiscence, intraabdominal abscess

\begin{tabular}{|c|c|c|c|c|c|}
\hline & & $\frac{\text { Control }}{n(\%)}$ & $\frac{\text { Krill oil }}{n(\%)}$ & $\frac{\text { Fish oil }}{n(\%)}$ & ${ }^{\mathrm{a}} \mathbf{p}$ \\
\hline \multicolumn{6}{|c|}{$\begin{array}{l}\text { Anastomoses } \\
\text { dehiscence }\end{array}$} \\
\hline \multirow[t]{2}{*}{$3^{\text {rd day }}$} & No & $6(85.7)$ & $7(100)$ & $6(85.7)$ & 1.000 \\
\hline & Yes & I (I4.2) & $0(0)$ & I (I4.2) & \\
\hline \multirow[t]{3}{*}{$7^{\text {th }}$ day } & No & $7(100)$ & $7(100)$ & $7(100)$ & 1.000 \\
\hline & Yes & $0(0)$ & $0(0)$ & $0(0)$ & \\
\hline & ${ }^{b} p$ & 0.559 & 0.192 & 0.462 & \\
\hline \multicolumn{6}{|c|}{$\begin{array}{l}\text { Intra-abdominal } \\
\text { abscess }\end{array}$} \\
\hline \multirow[t]{2}{*}{$3^{\text {rd }}$ day } & No & $4(66.6)$ & $5(7 \mid .4)$ & $5(83.3)$ & 1.000 \\
\hline & Yes & $2(33.3)$ & $2(28.6)$ & I (I6.7) & \\
\hline \multirow[t]{3}{*}{$7^{\text {th }}$ day } & No & $6(85.7)$ & $7(100)$ & $6(85.7)$ & 1.000 \\
\hline & Yes & I (I4.3) & $0(0)$ & I (I4.3) & \\
\hline & ${ }^{b} p$ & 1.000 & 0.462 & 1.000 & \\
\hline
\end{tabular}

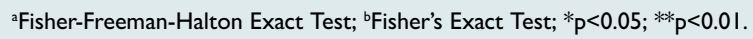

Bursting pressure values: Measurements of the bursting pressures of the anastomoses are demonstrated in Table 2. Significant anastomotic leakage suggestive findings (fecal con- tamination in the abdominal cavity, fecal peritonitis, anastomotic dehiscence) were observed in two rats (CO3: I, FO3: I). Also, bursting pressures of two rats were measured as 0 mmHg (KO3: I; FO7: I), which was accepted as anastomotic leakage. Statistically significant differences were not found between the bursting pressure measurements of the control, $\mathrm{KO}$ and FO group on the third day $(p=0.839)$. But bursting pressure measurements of $\mathrm{KO}$-applied group was significantly higher than other groups on the seventh day $(p=0.012)$.

Histological evaluation: The histological evaluation measurements are shown in Figure I. Inflammatory cell infiltration rate of $\mathrm{KO} 7$ and FO7 was lower than $\mathrm{CO} 7(\mathrm{p}=0.023)$. Fibroblast activity of FO3 is higher than $\mathrm{KO} 3$ and $\mathrm{CO} 3(\mathrm{p}=0.03)$. But the fibroblast activity of $\mathrm{KO}$-applied group was significantly higher on the seventh day. No significant difference was observed between the groups according to neoangiogenesis and collagen deposition measurements on the third day ( $p>0.05 ; p>0.05$, respectively). Neoangiogenesis and collagen deposition measurements of the $\mathrm{KO} 7$ group was significantly higher than other groups $(p=0.016 ; p=0.012$, respectively).

Hydroxyproline measurements: The anastomotic hydroxyproline measurements are shown in Table 3. Hydroxyproline measurements of $\mathrm{KO} 3$ and $\mathrm{KO} 7$ are higher than FO3 and FO7, but the difference is not statistically significant $(p=0.404 ; p=0.219$, respectively). Also, no statistically significant difference was observed between groups $\mathrm{CO} 3, \mathrm{KO} 3$,

Table 2. Evaluation of bursting pressure measurements

\begin{tabular}{|c|c|c|c|c|c|}
\hline & & Control & Krill oil & Fish oil & ${ }^{a} \mathbf{p}$ \\
\hline \multicolumn{6}{|c|}{ Bursting pressure $(\mathrm{mmHg})$} \\
\hline \multirow[t]{2}{*}{$3^{\text {rd day }}$} & Minimum-maximum & $0-30$ & $0-12$ & $0-10$ & \\
\hline & Mean \pm SD & $9.29 \pm 10.9$ & $5.7 I \pm 5.4$ & $6.57 \pm 4.58$ & 0.839 \\
\hline \multirow[t]{2}{*}{$7^{\text {th }}$ day } & Minimum-maximum & $0-180$ & $220-300$ & $140-240$ & \\
\hline & Mean $\pm S D$ & $131.43 \pm 62$ & $242.86 \pm 76.1$ & $191.43 \pm 51.2$ & $0.012^{*}$ \\
\hline${ }^{b} \mathrm{p}$ & & $0.014^{*}$ & $0.002^{* *}$ & $0.002^{* *}$ & \\
\hline
\end{tabular}

aKruskal Wallis Test; 'Mann-Whitney U Test; ${ }^{*} \mathrm{p}<0.05$; ** $\mathrm{p}<0.01 . \mathrm{SD}$ : Standard deviation.

Table 3. Evaluation of hydroxyproline measurements

\begin{tabular}{|c|c|c|c|c|c|}
\hline & & Control & Krill oil & Fish oil & ${ }^{\mathrm{a}} \mathbf{p}$ \\
\hline \multicolumn{6}{|c|}{ OH-proline ${ }^{* * * *}(\mathrm{ng} / \mathrm{ml})$} \\
\hline \multirow[t]{2}{*}{$3^{\text {rd }}$ day } & Minimum-maximum & $0.2-1.9$ & $0-7.2$ & $0-1.4$ & 0.404 \\
\hline & Mean $\pm S D$ & $0.65 \pm 0.5$ & $2.72 \pm 2.9$ & $0.59 \pm 0.5$ & \\
\hline \multirow[t]{3}{*}{$7^{\text {th }}$ day } & Minimum-maximum & $0-11.2$ & I. $2-28.8$ & $0.8-13.7$ & \\
\hline & Mean \pm SD & $5.13 \pm 5.2$ & $7.95 \pm 10$ & $5.86 \pm 4.9$ & $0.002^{* *}$ \\
\hline & ${ }^{b} p$ & $0.014^{*}$ & $0.002^{* *}$ & $0.002^{* *}$ & \\
\hline
\end{tabular}

aKruskal Wallis Test; 'Mann-Whitney U Test; "p<0.05; ** $p<0.01$; ${ }^{*}$ Hydroxyproline. SD: Standard deviation. 


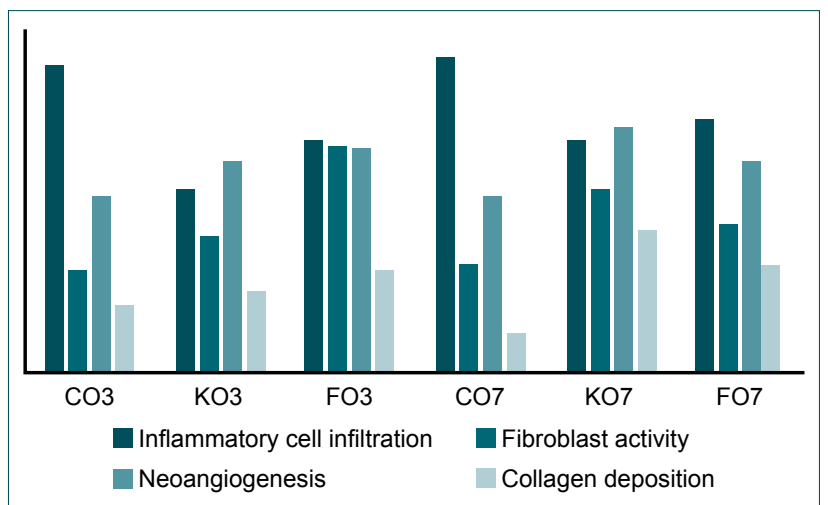

Figure 1. The histological evaluation measurements.

and FO3 $(p=0.404)$. However, hydroxyproline measurements of the $\mathrm{KO} 7$ group were significantly higher than the $\mathrm{CO} 7$ and FO7 groups.

\section{DISCUSSION}

Our findings suggest that both $\mathrm{FO}$ and $\mathrm{KO}$ have a positive influence on wound healing following colon anastomosis. Moreover, KO has more positive effects on anastomotic healing than FO.

Anastomotic leakage remains a challenge that is associated with morbidity and mortality in patients undergoing colorectal surgery. ${ }^{[13]}$ Leakage at the site of anastomosis has been reported to contribute to an increase in the length of hospital stays and medical costs. ${ }^{[14-16]}$ Prevention of anastomosis leakage remains the most critical issue. Hence, highlighting the need for new treatment strategies to prevent anastomosis leakage is crucial. Since the anastomotic strength is very limited in the first days of surgery, the risk of anastomotic dehiscence is utmost, even if the surgical process is performed under optimal circumstances. ${ }^{[12]}$ Therefore, the early days of surgery are critical for anastomotic healing. Many investigators have researched on anastomotic wound healing process. ${ }^{[1,14,17-20]}$ And these studies also investigated the effectiveness of diverse systemic or local applied agents on the anastomotic healing process. ${ }^{[17,21,22]}$

Inflammation during wound healing process stimulates the formation of fibrous bands between serosal surfaces ultimately. ${ }^{[23]}$ First seven days is the most critical time for peritoneal fibrous adhesion formation in the rat model. ${ }^{[12]}$ Karakas et al. ${ }^{[24]}$ demonstrated that the use of O3FA depresses intraperitoneal adhesion formation. The adhesion score of the KO groups is lower on the seventh day $(p=0.01)$, which shows that the utilization of $\mathrm{KO}$ reduces adhesion/fibrous band formation around the anastomosis. Many agents have been used to forestall adhesion formation by delimitating inflammatory reactions during peritoneal healing, thereby reducing the creation of a fibrinous network between serosal surfaces. ${ }^{[12-}$ ${ }_{14,17,19,20]}$ Although detecting the properties of $\mathrm{KO}$ that depress the formation of peritoneal adhesions may be an issue of another study, we think the administration of omega- 3 sources (either $\mathrm{KO}$ or $\mathrm{FO}$ ) decreases the inflammation on peritoneal surfaces in the critical stage of peritoneal wound healing.

Neutrophils migrate into the wound in the beginning stages of the inflammatory reaction. Activation of neutrophils in wound healing process happens to be secondary to inflammatory mediators. ${ }^{[25]}$ These inflammatory cytokines (TNF- $\alpha$, IL-I, IL-6, and other) are high enough to be measured in the systemic circulation and much higher levels in the abdominal exudate. ${ }^{[26]}$ Kuhn et al. ${ }^{[27]}$ demonstrated that suppressing inflammatory cytokines promotes intestinal healing. Because of the inflammatory and chemo-attractant mediators secreted secondary to colonic injury/surgery, activated neutrophils either in systemic circulation or in peritoneal cavity readily accumulates around the anastomosis. This rapid accumulation boosts inflammatory reaction around the anastomosis that may disrupt the anastomotic healing if the collection is exaggerated. ${ }^{[12,28]}$ In this study, control groups had more inflammatory cell infiltration. Similar to our results, other studies reported the O3FA to create an impairment over inflammatory cell migration, thus reducing the inflammatory reaction. ${ }^{[8,29]}$

Fibroblast cells and neovascularization promote the synthesis of collagen and mucopolysaccharides to increase anastomotic strength. ${ }^{[30]}$ Migration of endothelial cells begins on the second and third days of the inflammation, and this process is completed by the sixth or seventh day. ${ }^{[1]}$ The fibrinopurulent exudates fill anastomotic space in peritoneal cavity. This fibrinopurulent exudates repress collagen and new blood vessel formation and, as a result, that the anastomosis heals by secondary intention. ${ }^{[32]}$ Lobraico et al. ${ }^{[33]}$ revealed that KO supplementation has a positive effect on endothelial function. Fahs et al. ${ }^{[34]}$ also demonstrate the positive impact of FO supplementation on endothelial function. Zeng et al. ${ }^{[35]}$ showed that O3FA attenuates the fibroblast cells. In this study, fibroblast activity and neoangiogenesis were higher in both KO-supplemented groups. We believe anti-inflammatory activity of n-3 polyunsaturated fatty acids, eicosapentaenoic acid, and docosahexaenoic acid promote the endothelial cell activity.

In clinical practice, the physical strength of the anastomosis is not an ideal parameter to assess the healing of colonic anastomosis; nonetheless, bursting pressure was used as an indirect method to evaluate anastomotic integrity. ${ }^{[4]} \mathrm{We}$ found that bursting pressure of the animals treated with both $\mathrm{KO}$ and $\mathrm{FO}$ is higher than control groups, whereas there was no significant difference in the bursting pressures between the $\mathrm{KO}$ and $\mathrm{FO}$ groups on the third day. However, bursting pressure of the $\mathrm{KO} 7$ group was significantly higher $(\mathrm{p}=0.0 \mathrm{I} 2)$. This result may be indirectly suggest that $\mathrm{KO}$ may provide an advantage over FO in ensuring anastomosis integrity.

The most crucial factor in anastomotic healing is collagen, which forms the tensile strength of submucosal connective tissue. ${ }^{[36]}$ Increased inflammation may cause excessive collagenol$y$ sis, and the anti-inflammatory function of O3FA might inhibit 
collagenolysis during tissue healing. ${ }^{[37]}$ Hydroxyproline levels can be used to assess collagen formation during wound healing. Hydroxyproline is a component of collagen that was shown to be positively correlated with the collagen amount and strength of anastomosis. ${ }^{[2]}$ In this study, hydroxyproline levels were higher on day 7 compared to those on day 3 among all groups which are an expected result of the wound healing process. We also found that hydroxyproline levels of the KO-treated animals were higher than FO-treated animals $(p=0.002)$. The higher level of hydroxyproline in the $\mathrm{KO} 7$ group may be a sign of a better collagen formation than the FO groups. These results suggest that both $\mathrm{KO}$ and $\mathrm{FO}$ might increase the strength of the anastomosis by inducing collagen formation, but $\mathrm{KO}$ may provide better anastomotic strength. And, $\mathrm{KO}$ and $\mathrm{FO}$ might also decrease collagenolysis via an anti-inflammatory action, but further investigations are needed on this issue.

Collagen is an essential protein in all stages of the wound healing process. It is mandatory to ensure anastomotic integrity-strength for complete anastomotic healing. ${ }^{[38]}$ The balance between pre-existing fibrillary collagen cleaved by matrix metalloproteinase 8 (synthesized by neutrophils, macrophages, and bacteria located in wound side) and de novo collagen synthesis composes wound collagen amount on first three days of wound healing. Although previous studies have shown de novo synthesis begins $10^{\text {th }}$ hour of the tissue injury, new collagen synthesis reaches its maximal capacity on the fourth day of the surgery. ${ }^{[39]}$ De novo synthesized collagen amount reaches a climax point between the fifth and seventh days after tissue damage, and this newly synthesized collagen maintains the integrity and strength of anastomosis. ${ }^{[12]}$ For a reason explained above, we preferred to evaluate anastomotic tissue on the third and seventh days that exemplify the early and late phases of wound healing of anastomotic tissue. In this study, the collagen deposition levels and hydroxyproline measurements do not differ between $\mathrm{KO}$ and $\mathrm{FO}$ on the early and late phases of the anastomosis. But both values of the $\mathrm{KO} 7$ group are higher than the control and FO groups on the seventh day, which are other indirect signs of $\mathrm{KO}$ improving anastomotic strength and integrity by stimulating better collagen synthesis.

\section{Limitations}

There were several limitations of our study. Although we tried to accommodate the number of rats using power analysis, the small sample size was the first limitation of our study. Another limitation was that the effect of $\mathrm{FO}$ and $\mathrm{KO}$ on colonic anastomosis was evaluated only under normal condition without disease activity. Thus, our study failed to reflect the real clinical experience. Finally, the marine-derived oil metabolism in rats is unknown and may differ from humans. Despite these limitations, we assumed that our study well demonstrated solely the effect of $\mathrm{KO}$ and $\mathrm{FO}$ on colonic anastomotic healing.

\section{Conclusion}

Our experimental investigation has shown that both $\mathrm{KO}$ and
FO supplementation in patients before colorectal surgery may reduce some risk factors of anastomotic leakage by improving endothelial functions, neoangiogenesis, de novo collagen synthesis, and reducing excessive inflammation. Compared to the wound healing of colon anastomosis, $\mathrm{KO}$ is better than FO. We also concluded that $\mathrm{KO}$ might be a new alternative and preferable omega-3 source.

\section{Conflict of interest: None declared.}

\section{REFERENCES}

1. Ulven SM, Holven KB. Comparison of bioavailability of krill oil versus fish oil and health effect. Vasc Health Risk Manag 2015;11:511-24.

2. Tou JC, Jaczynski J, Chen YC. Krill for human consumption: nutritional value and potential health benefits. Nutr Rev 2007;65:63-77. [CrossRef]

3. Bhandari A, Woodhouse M, Gupta S. Colorectal cancer is a leading cause of cancer incidence and mortality among adults younger than 50 years in the USA: a SEER-based analysis with comparison to other young-onset cancers. J Investig Med 2017;65:311-5. [CrossRef]

4. Neumann PA, Twardy V, Becker F, Geyer C, Schwegmann K, Mohr A, et al. Assessment of MMP-2/-9 expression by fluorescence endoscopy for evaluation of anastomotic healing in a murine model of anastomotic leakage. PLoS One 2018;13:e0194249. [CrossRef]

5. Nordentoft T. Sealing of gastrointestinal anastomoses with fibrin glue coated collagen patch. Dan Med J 2015;6:B5081.

6. Kofoed SC, Calatayud D, Jensen LS, Jensen MV, Svendsen LB. Intrathoracic anastomotic leakage after gastroesophageal cancer resection is associated with reduced long-term survival. World J Surg 2014;38:114-9.

7. Rutegård M, Lagergren P, Rouvelas I, Lagergren J. Intrathoracic anastomotic leakage and mortality after esophageal cancer resection: a population-based study. Ann Surg Oncol 2012;19:99-103. [CrossRef]

8. Terzi C, Sevinç AI, Koçdor H, Oktay G, Alanyali H, Küpelioğlu A, et al. Improvement of colonic healing by preoperative rectal irrigation with short-chain fatty acids in rats given radiotherapy. Dis Colon Rectum 2004;47:2184-94. [CrossRef]

9. Ekçi B, Karabicak I, Atukeren P, Altinlio E, Tomaoglu K, Tasci I. The effect of omega-3 fatty acid and ascorbic acid on healing of ischemic colon anastomoses. Ann Ital Chir 2011;82:475-9.

10. van der Ham AC, Kort WJ, Weijma IM, van den Ingh HF, Jeekel H. Effect of antibiotics in fibrin sealant on healing colonic anastomoses in the rat. Br J Surg 1992;79:525-8. [CrossRef]

11. Phillips JD, Kim CS, Fonkalsrud EW, Zeng H, Dindar H. Effects of chronic corticosteroids and vitamin A on the healing of intestinal anastomoses. Am J Surg 1992;163:71-7. [CrossRef]

12. Uludag M, Citgez B, Ozkaya O, Yetkin G, Ozcan O, Polat N, et al. Effects of amniotic membrane on the healing of primary colonic anastomoses in the cecal ligation and puncture model of secondary peritonitis in rats. Int J Colorectal Dis 2009;24:559-67. [CrossRef]

13. Holmer C, Praechter C, Mecklenburg L, Heimesaat M, Rieger H, Pohlen $\mathrm{U}$. Anastomotic stability and wound healing of colorectal anastomoses sealed and sutured with a collagen fleece in a rat peritonitis model. Asian J Surg 2014;37:35-45. [CrossRef]

14. Daglioglu YK, Duzgun O, Sarici IS, Ulutas KT. Comparison of platelet rich plasma versus fibrin glue on colonic anastomoses in rats. Acta Cir Bras 2018;33:333-40. [CrossRef]

15. Ersoz N, Ozler M, Topal T, Uysal B, Poyrazoglu Y, Simsek K, et al. Effects of ozone treatment on experimental colon anastomosis in rats. Eur Surg 2016;48:122-8. [CrossRef]

16. Strunden MS, Heckel K, Goetz AE, Reuter DA. Perioperative fluid and volume management: physiological basis, tools and strategies. Ann Intensive Care 2011;1:2. [CrossRef] 
17. Kiyama T, Onda M, Tokunaga A, Yoshiyuki T, Barbul A. Effect of early postoperative feeding on the healing of colonic anastomoses in the presence of intra-abdominal sepsis in rats. Dis Colon Rectum 2000;43:S54-8. [CrossRef]

18. Aebi H. Catalase in vitro. Methods Enzymol 1984;105:121-6.

19. Barlas AM, Kuru S, Kismet K, Cavusoglu T, Bag YM, Senes M, et al. Rectal application of argan oil improves healing of colorectal anastomosis in rats1. Acta Cir Bras 2018;33:565-76. [CrossRef]

20. Yamada F, Endo N, Miyatake S, Ebisu G, Hino K. Enteral feeding with low-methoxyl pectin accelerates colonic anastomosis healing in rats. $\mathrm{Nu}$ trition 2018;45:94-8. [CrossRef]

21. Cancan G, Teksoz S, Aytac E, Arikan AE, Erman H, Uzun H, et al. Effects of Ankaferd on anastomotic healing of colon. J Invest Surg 2014;27:1-6.

22. Ersoy OF, Ozkan N, Ozsoy Z, Kayaoglu HA, Yenidogan E, Celik A, et al. Effects of melatonin on cytokine release and healing of colonic anastomoses in an experimental sepsis model. Ulus Travma ve Acil Cerrahi Derg. 2016;22:315-21.

23. Mutsaers SE, Prêle CM, Pengelly S, Herrick SE. Mesothelial cells and peritoneal homeostasis. Fertil Steril 2016;106:1018-24. [CrossRef]

24. Karakas DO, Yigitler C, Gulec B, Kucukodaci Z, Ipcioglu OM, Akin ML. Comparison of $4 \%$ icodextrin and omega 3 Fatty acids in prevention of peritoneal adhesions. Indian J Surg 2014;76:181-6. [CrossRef]

25. Koh TJ, DiPietro LA. Inflammation and wound healing: the role of the macrophage. Expert Rev Mol Med 2011;13:23. [CrossRef]

26. Zhu P, Liang Z, Fu J, Chen W, Wang Z, Jiang H, et al. Procalcitonin in abdominal exudate to predict prolonged postoperative ileus following colorectal carcinoma surgery. Int J Biol Markers 2013;28:187-91.

27. Kuhn KA, Manieri NA, Liu TC, Stappenbeck TS. IL-6 stimulates intestinal epithelial proliferation and repair after injury. PLoS One 2014;9:114195. [CrossRef]

28. Teke Z, Aytekin FO, Aydin C, Kabay B, Yenisey C, Sacar S, et al. Effects of pyrrolidine dithiocarbamate on healing of colonic anastomoses in the cecal ligation and puncture model of intraperitoneal sepsis in rats. World J Surg 2007;31:200-9. [CrossRef]

29. Vigerust NF, Bjørndal B, Bohov P, Brattelid T, Svardal A, Berge RK. Krill oil versus fish oil in modulation of inflammation and lipid metabolism in mice transgenic for TNF- $\alpha$. Eur J Nutr 2013;52:1315-25. [CrossRef]

30. Mariggiò MA, Cassano A, Vinella A, Vincenti A, Fumarulo R, Lo Muzio L, et al. Enhancement of fibroblast proliferation, collagen biosynthesis and production of growth factors as a result of combining sodium hyaluronate and aminoacids. Int J Immunopathol Pharmacol 2009;22:485-92.

31. Oguido APMT, Hohmann MSN, Pinho-Ribeiro FA, Crespigio J, Domiciano TP, Verri WA Jr, et al. Naringenin Eye Drops Inhibit Corneal Neovascularization by Anti-Inflammatory and Antioxidant Mechanisms. Invest Ophthalmol Vis Sci 2017;58:5764-76. [CrossRef]

32. Saravanan M. A Comparative Study Between Single Versus Double Layered Intestinal Anastomosis. The Tamil Nadu Dr. M.G.R. Medical University Chennai 2015;600:032. [CrossRef]

33. Lobraico JM, DiLello LC, Butler AD, Cordisco ME, Petrini JR, Ahmadi R. Effects of krill oil on endothelial function and other cardiovascular risk factors in participants with type 2 diabetes, a randomized controlled trial. BMJ Open Diabetes Res Care 2015;3:e000107. [CrossRef]

34. Fahs CA, Yan H, Ranadive S, Rossow LM, Agiovlasitis S, Wilund KR, et al. The effect of acute fish-oil supplementation on endothelial function and arterial stiffness following a high-fat meal. Appl Physiol Nutr Metab 2010;35:294-302. [CrossRef]

35. Zeng Z, Yang H, Wang Y, Ren J, Dai Y, Dai C. Omega-3 Polyunsaturated Fatty Acids Attenuate Fibroblast Activation and Kidney Fibrosis Involving MTORC2 Signaling Suppression. Sci Rep 2017;7:46146. [CrossRef]

36. Adam AB, Özdamar MY, Esen HH, Günel E. Local effects of epidermal growth factor on the wound healing in esophageal anastomosis: An experimental study. Int J Pediatr Otorhinolaryngol 2017;99:8-12.

37. Curioni CC, Alves NNR, Zago L. Omega-3 supplementation in the treatment of overweight and obese children and adolescents: A systematic review. J Func Food 2019;52:340-7. [CrossRef]

38. Rieger H, Kruschewski M, Khalilullah F, Buhr HJ, Pohlen U. Bursting pressure, vascular integrity and collagen content of sutured and glued colorectal anastomoses in the rat model. 7 th World Congress on Trauma, Shock, Inflammation and Sepsis 2007;125-30.

39. Wilgus TA, Roy S, McDaniel JC. Neutrophils and Wound Repair: Positive Actions and Negative Reactions. Adv Wound Care (New Rochelle) 2013;2:379-88. [CrossRef]

\section{DENEYSEL ÇALIŞMA - ÖZET}

Deniz kaynaklı, iki farklı omega-3 yağ asidi kaynağının, krill yağı ve balık yağı, primer kolon anastomozlarının iyileşmesi üzerindeki etkilerinin kolektomi uygulanan Wistar albino sıçan modeli ile karşılaştırılması

\section{Dr. Murat Ferhat Ferhatoğlu, ${ }^{1}$ Dr. Taner Kıvılcım, ${ }^{1}$ Dr. Gürcan Vural, ${ }^{2}$ Dr. Abdulcabbar Kartal, ${ }^{1}$ Dr. Ali İlker Filiz, ${ }^{1}$ Dr. Abut Kebudi ${ }^{1}$}

\section{${ }^{1}$ İstanbul Okan Üniversitesi Tıp Fakültesi, Genel Cerrahi Anabilim Dalı, İstanbul}

${ }^{2}$ İstanbul Okan Üniversitesi Tıp Fakültesi, Patoloji Anabilim Dalı, İstanbul

AMAÇ: Deniz canlılarından gelen yağların farklı yağ asidi bileşimleri vardır. Balık yağı (FO), triasilgliserollere esterlenmiş yüksek oranda eikosapentaenoik ve dokosahekssaenoik asit içeriğine sahipken, krill yağında $(K O)$ yağ asitleri temel olarak fosfolipidlere esterlenir. Bu çalışmada, iki farkl, omega-3 yağ asidi kaynağının kolon anastomozu uygulanan sıçan modelinde, anastomoz iyileşmesindeki etkinliğini karşılaştırdık.

GEREÇ VE YÖNTEM: Çalışmada 42 erkek Wistar albino sıçan kullanıldı. Yedi sıçandan oluşan altı grup şu şekilde oluşturuldu: CO3: Üçüncü günde sakrifiye edilen sol kolon anastomu yapılan sıçan (kontrol grubu); KO3: Üçüncü günde sakrifiye edilen sol kolon anastomozu yapılan sıçan + oral KO; FO3: Üçüncü günde sakrifiye edilen sol kolon anastomozu yapılan sıçan + oral FO; CO7: Yedinci günde sakrifiye sol kolon anastomozu yapılan sıçan (kontrol grubu); KO7: Yedinci günde sakrifiye edilen sol kolon anastomozu yapılan sıçan + oral KO; FO7: Yedinci günde sakrifiye edilen sol kolon anastomozu yapılan sıçan + oral FO. Peritoneal adezyonlar, anastomoz patlama basınçları, hidroksiprolin düzeyleri ve anastomotik dokunun histolojik özellikleri değerlendirildi.

BULGULAR: Kril yağı grubunun patlama basıncı ve hidroksiprolin ölçümleri, yedinci günde FO grubundan anlamlı olarak daha yüksekti (sırasıyla, $p=0.012 ; p=0.002$ ). Ayrıca, enflamatuvar hücre infiltrasyonuna, fibroblast aktivitesi, neoanjiyogenez ve kollajen birikimine göre gruplar arasında, yedinci günde $K O$ grubu lehine istatistiksel olarak anlamlı bir fark gözlendi (sırasıyla, $p=0.023 ; p=0.028 ; p=0.016 ; p=0.012$ ).

TARTIŞMA: Kolorektal cerrahi öncesi hastalara hem KO hem de FO desteği anastomoz kaçağı riskini azaltabilir ancak KO daha iyi bir omega-3 kaynağı olarak öne çıkmaktadır.

Anahtar sözcükler: Anastomoz iyileşmesi; balık yağı; krill yağı; omega-3 yağ asitleri; primer kolon anastomozu.

Ulus Travma Acil Cerrahi Derg 2019;25(4):324-330 doi: 10.14744/tjtes.2019.0305 I 